\title{
Taking Turns: Democracy to Come and Intergenerational Justice*
}

\author{
Matthias Fritsch
}

\begin{abstract}
In the face of the ever-growing effect the actions of the present may have upon future people, most conspicuously around climate change, democracy has been accused, with good justification, of a presentist bias: of systemically favouring the presently living. By contrast, this paper will argue that the intimate relation, both quasi-ontological and normative, that Derrida's work establishes between temporality and justice insists upon another, more future-regarding aspect of democracy. We can get at this aspect by arguing for two consequences of the deconstructive affirmation of sur-vivre, of the alterity of death in life. Firstly, justice is not first of all justice for the living, but intergenerational from the start. This is so because no generation coincides with itself; rather, it dies and is reborn at every moment, and so-and this is the second consequence-consists in taking turns. Affirming life as living-on means affirming that it involves exchanging life's stations, as the young become the old, and the unborn become the dead. In this sense, the justice of living-on, I will argue, shares an essential feature with democracy, whose principle of exchanging the rulers with the ruled led Derrida to characterize it in terms of the wheel. Democracy consists in the principled assent to power changing hands, a switchover life demands of every generation at every turn. This assent further requires an acceptance of the gift of inheritance without which no life can survive. But as the gift can also never be fully acknowledged or appropriated, it must be
\end{abstract}

Derrida Today 4.2 (2011): 148-172

DOI: $10.3366 /$ drt.2011.0015

(C) Edinburgh University Press

www.eupjournals.com/drt 
passed on to the indefinite, unknown future, in a turning that is the time of life.

Keywords. Derrida, democracy to come, intergenerational justice, double affirmation, gift, inheritance

To view, thro the calm sedate Medium of Reason, the Influence which the Establishments now proposed may have upon the Happiness or Misery of Millions yet unborn, is an Object of such 'Magnitude, as absorbs, \& in a Manner suspends the Operations of human Understanding.' - George Mason in a letter to his son, written at the beginning of the US constitutional convention, 1787 (Mason 1970, 3:892-3).

'The miracle that saves the world, the realm of human affairs, from its normal, 'natural' ruin is ultimately the tact of natality, in which the faculty of action is ontologically rooted. It is, in other words, the birth of new men and the new beginning, the action they are capable of by virtue of being born.'-Hannah Arendt, The

Human Condition (Arendt 1958, 247)

'What resists analysis is birth and death: always the origin and the end of a world.'- Jacques Derrida (2002a, 104).

\section{The Bobbing Wheel}

Derrida's most extensive discussion of 'democracy to come', at least in the texts published so far, is now to be found in the first of two essays in Rogues, 'The Reason of the Strongest (Are there Rogue States?)'. The essay is divided into ten sections and, prior to the first section, begins with an untitled exordium, distinct from the preface to the entire book. The exordium suggests at the very outset, rather cryptically, that democracy has a 'deep affinity' with the figure of the 'ellipsis' (Derrida 2005a, 1/19). ${ }^{1 .}$ Derrida tells us that the ellipsis is not only an omission or a lack, but a figure of the circle (a 'curved figure', the English translation says) with more than one focal point. Instead of commenting on the difference between an ellipse and a circle and on the alleged affinity of the former with democracy, Derrida then moves on to give us an 'elliptical sending', a sentence about the relation between democracy, time and the gift (we will come back to it), a sending meant to encapsulate the essay we are about to read. In their excellent translation, Pascale-Anne 
Brault and Michael Naas do not flag the fact that English splits up the French polysemous homonym 'ellipse' into two words between which they had to decide: 'ellipsis' for the figure of speech ('omission') and 'ellipse' for the mathematical figure. The latter refers to an egg-shaped or oval circle with two focal points, obtained by slicing a cone at a plane not perpendicular to the cone's axis. (For the sake of his convenience, Derrida says that an ellipse has 'more than one focus' (Derrida 2005a, 1/19) whereas in fact it has two foci, in addition to the centre point that in this case loses its exclusivity, as it were, despite the fact that the foci are somewhat arbitrarily chosen on the major axis so that they can be varied and multiplied.)

Given that the English translation de-emphasizes the geometric figure (for the translators decided for the figure of speech ${ }^{2}$ ), the significance of the French 'ellipse', already abandoned by Derrida - the text of Rogues, while speaking abundantly of the circle, will not refer to the geometric ellipse again, and in fact mentions the figure of speech only on two further, non-technical occasions (16/36 and 111/156) - does not stand out as much as it could. The translators' decision is understandable not only because in English the adjective 'elliptical' may be used in both senses (an elliptical phrase or an elliptical circle), but also because the English 'ellipsis' (in the sense of omission) is closer to the Greek origin, which derives from 'elleipein': 'to leave out, to fall short'. Already Apollonius of Perga ( $3^{\text {rd }}$ century B.C.E. $)$, it seems, applied the Greek term to the geometric figure 'because the conic section of the cutting plane makes a smaller angle with the base than does the side of the cone, hence, a "falling short". ${ }^{3 .}$ Both senses then refer to a deficit; in the geometric case, however, the shortfall results from an excess rather than from a simple lack or omission: for an ellipse has, as it were, two centres too many.

Despite the fact that Derrida does not mention it again, it is helpful to think the mathematical ellipse as inflecting all the turnings and turns, the torsions and tortures, the rotations, revolutions, and the wheels that are such recurring figures in Rogues. (Four of the ten chapter titles refer to the wheel, the roue, or the 'by turns', including the first three.) If democracy has something to do with the wheel, then its motion is not uniform and linear: an 'elliptical wheel', if you can figure it, would wobble, tremble, bob up and down, in the way, perhaps, that Derrida will later speak of the 'turnings of a circular machine that does not work or turn just right [qui ne tourne pas rond]' (Derrida 2005a, 7/27). Given a sufficient distance between the focal points, such an oval-shaped wheel might not be able to move forward at all, at least not in any sense we could call a rolling movement. The oval wheel, if not already wobbling along, would also need a kick-start: it would not begin turning without 
a strong (perhaps revolutionary) push that would have to be the greater the larger the distance between the focal points it circumscribes and binds together. Nor would its turning begin at a take-off point clearly marked, what in a true circle would be its one and only centre; the starting point of this wheel would be multiple. An 'elliptical turning' or an 'elliptical return' would be one that does not circle around one centre or come back to its true starting point.

The closer the foci are to one another, the better their cooperation in generating a smooth motion: if in fact the foci overlap with the centre point, we have a regular circle. (Mathematically speaking, the circle is a special kind of ellipse. This makes of perfect centrality, and optimal turning or rolling, an aberration: wobbling is the norm.) Further, the movement of the elliptical wheel would not roll continuously, but would have to begin again at each turn, requiring a discontinuous, stuttering motion, as if each turn had to take over its predecessor's motion, but on its own terms, with a new thrust. The greater the separation between its foci, and hence its terms, the greater is the discontinuity in the nonetheless also still continuous motion. And the larger the distance, the harder it is for the foci to take turns in bobbing up and down, to replace each other at the top and the inevitable bottom. Going back to Aristotle and Plato on political office-sharing later in the text, Derrida defines democracy - which is for him not merely a form of government but rather a dimension or 'experience' of the political more generally (26/48) - precisely by such a taking turns [tour à tour, in ancient Greek, kata meros] in ruling and being ruled (24/46, referencing Aristotle's Politics 1317b). ${ }^{4}$. When one generation of rulers is on top, then the other is on the receiving end; when the turning point comes and one generation has to let go, then the relinquishing of control and activity is gradual to the point where we reach equilibrium, then another takes over.

In his typically elliptical fashion, Derrida comments on his introduction of the ellipse/ellipsis: "We are thus already between the "minus one [moins un]" and the "more than one [plus d'un]"' (1/19). More than one centre means no centre (i.e., minus one) if the latter is defined by its exclusivity. As well, plus d'un can not only mean 'more than one' but also 'more of one' or 'no more one', implying a struggle for hegemony of one focal point over the others (cf. Derrida's seemingly approbatory reference to Laclau and Mouffe's work on hegemony at Derrida 1994, 180 n.31). Hence, the rolling movement, however wobbly, points to a centre around which it turns (Derrida will shortly call this 'the strange necessity of the zero'; Derrida 2005a, 12-13/32), but with the ellipse, the centre fails to live up to it; it falls short. The 'minus one' results from an excess that combines the two senses of the 
French 'ellipse', giving us a kind of circle that lacks a single centre, turning around more than one point. The Copernican or heliocentric revolution - itself a turning point in the history of dethroning mankind's narcissism, the first trauma of Freud's three world-historical 'lesions' [Kränkungen] (Derrida 1994, 97f.; cf. Derrida 2009, 131) - did not even give us a single new centre. After Copernicus, it was Kepler who found that the orbit of the earth, itself an oval rather than perfectly spherical body, is elliptical, with the centre of the sun merely one of its focal points.

This cosmological tweak - or, to put it more paradoxically, this cosmic disorder ('cosmos' meaning 'order' in ancient Greek) - is not without its political significance in 'our' times, times in which the originally Greek concept of democracy globalizes itself, or-to avoid hiding hegemonic interests under the blanket of a seemingly inevitable, auto-affective process - is being globalized, to cover the entirety of the earth. Rogues goes on to suggest that a certain kind of political theology is still at play in this globalizing movement. This kind supposes the roundness of the earth and its movement as required for cosmopolitical democracy, for it transfers the self-referential circularity of divine or monarchical power onto democratic popular sovereignty. This is why Derrida does not find innocuous Tocqueville's early $19^{\text {th }}$ century analogy between God's rule over the universe and the American people's rule over its political world (Derrida 2005a, 14/34). Rather, the analogy recalls the prime desirability, pure power (energeia) and perfect rotation of Aristotle's theo-cosmo-genic unmoved mover around its own axis (15/35). Perhaps it is only if we hold on to the view of sovereign power as spherical but replace the mistaken Ptolemaic worldview with a heliocentric (but also still elliptical) 'vision of the world determined by the spherical roundness of the globe' (18/39), that we can dream of replacing God with the people as the force 'ruling over the universe' and over what is living in it. It is as if we could extend the power of democracy to the round and rotating globe only because we figure-falsely, or elliptically, we just learned - the earth as round and its rotation as singularly centred. The cosmopolitical project, laudable as it is, would have to begin by questioning the desire for perfect roundness, desire as circling around and coming back to itself, to acknowledge 'another truth of the democratic, namely, the truth of the other [une autre vérité $d u$ démocratique, la vérité de l'autre]', of 'disseminal multiplicity' and of the unexpected, the 'anonymous "anyone"' (14/35). ${ }^{5}$.

Despite being well-known, we should recall here that in his early works, the beginning of deconstruction, Derrida made the absent or 
multiple centre one of its hallmarks in contradistinction to, for instance, the structuralism of Lévi-Strauss or Saussure, or indeed the entirety of Western metaphysics. In the often anthologized and now canonical 'Structure, Sign, and Play in the Discourse of the Human Sciences', Derrida argues that the centre of a structure gives, or is supposed to give, the substitutions and turnings within it a firm ground that is itself not substitutable (Derrida 1978b, 279). The centre grounds totality and yet, renders it incomplete, as the centre is and is not part of its substitutable elements. In belonging and yet not belonging to history as the field of such substitutions, the centre may also be the origin or the end of history, allowing thus archaeology and eschatology or teleology as the principal subject matter of deconstruction. The latter would thus begin, in Nietzsche, Freud, and Heidegger, without a single centre and without a simple origin, responding to this history of the centre but in such a way as to break with it, a break that is also a repetition (Derrida 1978b, 280).

If we now return to the opening lines of the most extensive of Derrida's essays on democracy to come, we should note that the more immediate point of referring to ellipse was to introduce an elliptical sending meant to capture, in one line, the theme and thesis of the entire essay. 'The elliptical sending would arrive by e-mail, and we would read: "The democracy to come: it is necessary that it give the time there is not"' (Derrida 2005a, 1/19). The elliptical structure is thus related, on the one hand, and in the sense indicated by the 'minus one', to a time that one does not have or control (are not all emails written too quickly?), but to which one is all the more relentlessly subject as to the 'the mortality of the day, the undeniable finitude of the ephemeral' (1/19). On the other hand, and as a 'more than one', this finitude is linked to an ineluctable iteration, the 'repetition that is never repeated' (1/19), and thus to the figure of re-turn (re-tour), turnings (les tours), and succession or 'by turns' (tour-à-tour). The elliptical sending links democracy, the democratic imperative or 'il faut' (it is necessary, one must), to a rotating movement in which there is a taking turns, a temporal gift-giving or giving of time of the one to the other. As Derrida argues in Given Time (Donner le temps), giving is above all to give time, not only because giving one's time to the other is a supreme giving as it is to give (a part of) oneself, but because every gift requires time: proceeding from a prior gift, it gives to the other in the unpossessable future that may always include the donor's death (Derrida 1992c).

Sovereignty in general, and modern democratic sovereignty in particular, cannot but disavow, in the instant of the exceptional 


\section{Matthias Fritsch}

decision', the time 'there is not' (Derrida 2005a, 109/154). And yet, sovereignty right away needs 'the event, time and the other' (109/154), and so remains tied to the finitude of time. The one must give way to the other in a repetition that also involves change, and a continuity that harbours discontinuity. If this giving of time to the other is demanded by the finitude of time 'itself', then this may indicate a basic relation between mortality and the democratic alternation regarding the governing and the governed. Giving way to another in death, willingly (if that is possible) but willy-nilly, accepting that one must pass on, would prepare one for democracy's taking-turns. And vice versa: affirming the iterability of time would bring a mortal one step toward this crucial feature of a regime, a form or basic experience of government. The bobbing rotation of the elliptical wheel, as we will see, indicates democracy's intergenerationality.

\section{Why Democracy to Come?}

Why should we be interested in the intergenerational dimension of democracy to come? In wondering whether today this vintage Derridean concept still contributes to our political discussions and concerns, we may note that democracy to come appears not to have been explored in relation to intergenerational justice, despite the fact that the latter is one of the most important and, despite the historically long view it requires, most urgent political themes today. The urgent salience of extending our moral and political horizon further into the future than has so far been the case is mandated by the fact that the rise of technology has extended the consequences of our actions and science our knowledge of these consequences. For good reasons, climate change is the most visible intergenerational concern in this area, but there are also the worries over the steep rise in the loss of biodiversity and similar environmental issues, while the passing on of massive national (and often private) debt to subsequent generations threatens to compromise their means to address the vital environmental concerns.

All of these complications are to be handled by the political form of government of which we said that, in various and uneven forms that often provide a mere ideological cover, is being globalized at the domestic and the international level. And it is this form that has been accused, with good reason, of a presentist bias: Dennis Thompson (coauthor, with Amy Gutmann, of the much acclaimed Democracy and Disagreement), argues that 'Democracies are systematically biased in favor of the present' (Thompson 2005, 246). The priority given to the 
present has been analyzed, politically and economically, in terms of the short-term thinking said to be brought on by democracy's relation to free market competition (in particular in post-Fordist capitalism; see Harvey 1990); by the frequent change of guards required by the electoral cycles of representative democracy (cf. Gardiner 2006; Garvey 2008; Dryzek 1996; Wood 2008), or by the mere fact of pure time preference on the part of the populace, perhaps justifying the implementation of a positive social discount rate on the part of its representatives (Thompson 2005; 2010). Indeed, democracy's rather poor record on sustainable practices and combating climate change has prompted some to speak of a 'failure of democracy' that would demand that we urgently replace sovereign democratic freedoms, in particular those regarding individual and collective self-determination, with 'survival' as 'the most fundamental value' (Shearman \& Smith 2007, 133; cf. Giddens 2009, 73; Tremmel 2006).

In the face of democracy's undeniable part in the failures in question, one might wonder whether the best strategy would not be to find refuge in a more autocratic regime, but instead to rethink democracy and its relation to time in particular. Given that deconstruction has always sought to question and to subvert 'presentism' in all its form, and that the deconstructive concept of democracy refers to a seeming concern for the future in its very name (la democratie à venir), it may be a promising avenue for such a rethinking-even if this promise asks for some deciphering, as Derrida rarely links the intergenerational concern for the unborn directly to democracy.

\section{Double Affirmation}

We should, then, continue by outlining the finitude (or indeed futurity) of time that Derrida associates so intrinsically with democracy. As the latter is a normative concept-it is to be preferred over other forms of government, and includes values such as equality, freedom, inclusivity, and, as indicated, gift-giving or taking turns-we will also have to wonder about the relation, if any, between temporal finitude and normativity. As the notions of time and finitude, mortality, and iterability are central issues in Derrida's multi-centred work, the relevant discussions of time are too lengthy to reconstitute here. We should recall, however, that Aristotle's Physics IV already read time in terms of succession, one 'now' taking turns with another (219a), and that this led to the famous conundrum according to which taking turns is, precisely, irreconcilable with the determination of the 'now' as indivisible presence 
or identity. In the wake of Heidegger's interpretation of being as a process of coming to presence that remains ineluctably tied to difference, absence, and unconcealment, thereby to nothingness and to death, Derrida's 'Ousia and Grammé' concluded from Aristotle's aporia that to allow one 'now' to give way to another, it must be thought in terms of a movement of temporalization in which it is divided from the start by what comes before and what comes after (Derrida 1982, 57/65). Time as succession entails that the 'now' exists only by being given its place or its space by the earlier 'now' as well as by itself already giving way to the next one. In Rogues, Derrida recalls this argument by pointing to the etymology of 'une fois' (once, one time) in the Latin 'vicis', whose meanings and associations range from 'time', 'succession', 'alternation', 'change' to 'vice versa', 'reciprocally' or 'by turns' (vicissim, per vices), 'in place of' (in vicem), to 'vicarious', 'vicissitude' and 'vicious circle' (Derrida 2005a, 6-7/25-26; cf. Derrida 2005b, 1-2).

If deconstruction proceeds from Heidegger's objections to the metaphysics of presence, it does so by positioning différance as 'temporalization and spacing [temporalisation et espacement], the becoming-time of space and the becoming-space of time, the "originary constitution" of time and space' (Derrida 1982, 8/8). This is because différance names a gap, an empty space, between elements of a 'system' of referral in which each element can only establish its self-identity by differing from others, and that means, by taking a 'detour' (détour) through all other elements. In its dependence on coming back to itself, self-identity is thus promised as standing at the end of this detour. However, the return to itself is deferred to a future - the future to come named in democracy to come-insofar as the system does not consist of a finite list of elements (see Fritsch 2011/12, forthcoming, on the two notions of the future implied here). That the system is 'infinite' or not closed results not from its actual magnitude but from the fact that each element is in a comparable situation: also on a tour, seeking to turn around itself or at least to return to itself, as if circling around its centre like a perfectly round wheel, but instead wobbling and bobbing as a result of finding itself referred to yet other elements that do not ever sit still so as to permit the constitutive relation to finally leave the other and be sent home. Hence, the reference to the other is an indeterminate renvoi, a send-off or delay in terms of which Derrida reads democracy (Derrida 2005a, 9/28; 34-39/58-64).

If identity is thus spaced-out, a little mad in not already coinciding with itself, it can be itself only by being identified, again and again, with 
itself. Its identity must rely, and from the beginning, on a repetition that intends the same. This is why one may, for example, elevate aiming at or commitment to the sameness of linguistic meaning across different contexts to the status of a transcendental condition of at least argumentative language use, an ineluctable promise every speaker makes to her hearers to mean the same by this or that word. ${ }^{6} \cdot$ In the case of a life capable of thus 'intending' or repeating itself - and we should briefly note that Derrida sees différance as co-extensive with life (Derrida 2001a, 108 ) and says that 'the old word vie perhaps remains the enigma of the political around which we endlessly turn' (Derrida 2005a, 4/22) - we may speak of a self-affirmation that expects to come back to itself despite its necessity of referring to and appropriating from others in the context into which différance will inevitably have cast it.

An identity, then, must always already have affirmed the preceding context, populated by other identities, to be what it is in the process of becoming. This affirmation is double (Derrida 1979, 85, 95ff., 118, 165; Derrida 2002a, 247; Derrida 1992b, 247; see also 'A Number of Yes' in Derrida 2008), a duplicity that also doubles itself. For it must affirm the self and the other, the one to affirm the other, but also, at the same time and in the same moment, repeat itself, that is, affirm its future repetition. Here are two (admittedly long) passages that make this point, the first concerning the double self-other where the affirmation of the other is put in terms of the 'welcome' that receives such an extensive treatment in the essay 'A Word of Welcome' (in Adieu, Derrida 1999):

The living ego is auto-immune ... To protect its life, to constitute itself as unique living ego, to relate, as the same, to itself, it is necessarily led to welcome [accueillir] the other within (so many figures of death: différance of the technical apparatus, iterability, non-uniqueness, prosthesis, synthetic image, simulacrum, all of which begins with language, before language). It must therefore take the immune defenses apparently meant for the non-ego: the enemy, the opposite, the adversary and direct them at once for itself against itself. (Derrida 1994, 141/224, emphasis in original)

Auto-immunity, of which Rogues has so much to say in relation to democracy, in ways that have been analyzed so well in the literature by now (see in particular Naas 2008, chapters $7 \& 8$; Rottenberg 2006; Hägglund 2008), results from the non-coincidence of the self with itself: to protect itself from the other, it would have to already know itself and its borders. ${ }^{7}$ But this 'itself' is generated only in the reference to the other, a relation both welcoming and protective, hospitable and 


\section{Matthias Fritsch}

hostile, unconditional and conditional. (Here, we should be reminded of what Politics of Friendship says about the indiscernibility, even the convertibility, of friend and enemy; Derrida 1997, 32, 71, 88, 163, 174, 216; cf. Fritsch 2008). The generation of the self in reference to alterity is never complete, never settled but always to be repeated. Hence, the self-other affirmation is duplicated by another double affirmation, this time regarding time:

[W] hat I call double affirmation ... is neither a descriptive observation nor a theoretical judgment; it is precisely an affirmation, with the performative characteristics that any affirmation entails. The 'yes' must also be a reply, a reply in the form of a promise. From the moment that the 'yes' is a reply, it must be addressed to the other, from the moment that it is a promise, it pledges to confirm what has been said. If I say 'yes' to you, I have already repeated it the first time, since the first 'yes' is also a promise of this 'yes' being repeated. To say 'yes' is to acquiesce, to pledge, and therefore to repeat. To say 'yes' is an obligation to repeat. This pledge to repeat is implied in the structure of the most simple 'yes'. There is a time and a spacing of the 'yes' as 'yes yes': it takes time to say 'yes'. A single 'yes' is, therefore, immediately double, it immediately announces a 'yes' to come and already recalls that the 'yes' implies another 'yes'. So, the 'yes' is immediately double, immediately 'yes-yes'. This immediate duplication is the source of all possible contamination that of the movement of freedom, of decision, of declaration, of inauguration by its technical or technical double. Repetition is never pure. (Derrida 2002a, 247)

Auto-immunity, we may say, is another way to state this impurity, this death in life, the conflictual co-implication of the one in the other and the second time in the first. In a by now well-known discussion, Derrida exemplifies autoimmunity by referring to the case of the 1992 elections in Algeria, which were suspended to prevent suspected non-democrats from coming to power (30-41). In welcoming its other (e.g., nondemocrats), democracy must also protect itself from them. ${ }^{8}$ Democracy can sustain itself only by promising to return to itself in relating to an other and in becoming other to itself. As we said, identity must of necessity be repeated, for an identity is never given once and for all. Each affirmation is already promised to a repetition that brings in the other once more (hence we should speak of iteration), so that the promise of return to oneself cannot ever be finally fulfilled; it is a promise made to a future forever to come (see Derrida in Caputo 1997, 27). As the 'first time' that is to be repeated never took place as such either, life is a 'living-on' suspended between the 'absolute past' that never took place as such and the 'future to come' that never will take place as such, in 
the 'now' present to itself. The structure of living-on, of sur-vival (survie) as the condition of any event (of anything at all happening), involves inevitable change in the suspension between past and future. The 'double affirmation' affirms the self as constitutively and differentially related to others, and thus also to its mortality. For this reason, the fundamental injunction to affirm self and other is necessarily contradictory (Derrida 1994, 7): it affirms the self as self, but also as other; it affirms the self as living, but also as dying and being reborn, such that every affirmation already promises its repetition as and beyond the same.

As the beginning of the last-cited passage makes clear, double affirmation is not a structure we can merely describe from a neutral standpoint. In describing it we must also perform it from where we are, in 'our' historical context, to which we thus respond with a promise. The welcome extended to the other is necessarily a response to a prior welcome by a preceding other. As Derrida puts in Adieu: 'the welcoming of the other (objective genitive) will already be a response: the yes to the other will already be responding to the welcoming of the other (subjective genitive), to the yes of the other' (Derrida 1999, 23). In affirming itself, a 'living ego' thus affirms, in what Derrida does not hesitate to call a 'blind submission' and 'obedience' (Derrida 1994, 7), its material and symbolic inheritance, its socio-economic context as well as its life-world, language, and tradition. This 'capital', productive and social, is not simply there, not receivable in a pre-packaged bundle, as it were, for it can exist as 'capital' only by being in the process of being repeated, appropriated in an inevitably new, indeed unpredictable context (cf. Derrida 2002b, 86f.).

Accepting an inheritance means promising to restate it in a different context, to remain faithful to it in such a way as to inevitably change (or 'iterate') it. Faithfulness, as Derrida insisted in so many different contexts, also demands unfaithfulness. Affirmation or fidelity, including to the democratic heritage, its ideas and its institutions, does not only relate us to the past but also to what is to come (Derrida 2005a, 4/22; Derrida 1994, xix). That is why we can also say, as Derrida does in Archive Fever, that the 'affirmation of the future to come: this is not a positive thesis. It is nothing other than the affirmation itself, the "yes", insofar as it is the condition of all promises or of all hope, of all awaiting, of all performativity, of all opening toward the future, whatever it may be' (Derrida 1996b, 67-8). In inheriting democracy, then, we affirm no identity whose border we know, no wheel whose turns of way and heading have been mapped out (cf. The Other Heading, Derrida 1992a). 


\section{The Democratic Filiation}

Associating democracy with an ellipse rather than a circle is to think it as a history without origin or end, as a freewheeling play of differences but also replacements. Democracy is part of a heritage that makes us say 'we' in the first place ('we democrats', for example). This heritage rolls along like the elliptical wheel and its lack of a single starting point: we cannot go back to the unambiguous origin of the concept of democracy to find out what it means. Given the unavailability of its archê, democracy remains to come: 'In the end, if we try to return to the origin, we do not yet know what democracy will have meant nor what democracy is. For democracy does not present itself; it has not yet presented itself, but that will come... We do not yet know what we have inherited' despite the fact that as heirs we are the delegates of this sending [envoi] or mission. 'This sending or putting off [renvoi] gestures toward the past of an inheritance only by remaining to come' (9/28). Democracy is given to us as a 'legacy', in the double sense of a selective gathering (legere) - Derrida argues that every inheritance comes with 'the injunction to reaffirm by choosing' (Derrida 1994, 16) - and a delegation, a bequest charging another with a mission, appointing her by a last will (legare) (Derrida 2005a, 9/28, and the further elaboration of the double sense of legacy at Derrida 2002c, 281).

Auto-immunity, we said, stems from the need to protect an identity that does not fully coincide with itself, that can be what it is only by being related to an alterity that lets it become an other. The democratic legacy, as all legacies, comes with an injunction to continue it; however, we cannot receive it as we do not know what it is or what exactly it demands of us. The 'debt' to the heritage, the one that allows us to be who we are becoming, is thus not one we could ever discharge, not even according to the model of an intergenerationally indirect reciprocity, of which it is at times said that its basic logic, the prohibition on freeriding, demands that one free oneself of one's debt to predecessors by paying forward an equivalent value to the next generation (Gosseries 2009). While democratic equality demands a calculation of equivalence, and rightly so, Derrida's well known insistence on the immeasurable, the incalculable and unconditional has this intergenerational significance: the debt to be paid forward is at once infinite in both 'directions', past and future. This is the reason why, as Rogues says at the beginning, the legatees receive an 'excessive gift', one that exceeds the present to discontinuously connect the past with the future. In this reception, the heirs must accept more than they can receive (Derrida 2005a, 4/22), so 
that their duty to give back (indirectly, to another other) is always also to 'give what one does not have', as Given Time puts it (Derrida 1992c, $3,159)$. Applied to responsibilities for future people, the excess renders it illegitimate to restrict the gift to the next generation, despite the fact that taking turns singles its members out, as we will see.

Accepting one's inheritance, including the democratic heritage, thus means promising to continue it in different, unpredictable circumstances. Affirming democracy means to seek to re-state it in its double truth: the truth of the self and the truth of the other (Derrida 2005a, 14/35). Democratic institutions must seek to maintain themselves as democratic across time-not simply because they want to be or ought to be democratic tomorrow as well, but because they would not even be able to identify themselves (or be identified by others) as democratic now, in this context here, if they did not aim at their continuity. In Rogues, this necessity of self-affirmation is analyzed as one meaning of the 'free wheel', what Derrida calls the 'ipsocentrism' or 'ipsocratism' of every subjective ability, 'I can' or sovereignty, whether individual or collective, democratic or not (10-18/29-39).

The requirement of circular return-the detour that deals with the other only to return to itself and so in an exclusionary way (36) - is, if you wish, the quasi-transcendental reason why democratic sovereignty stands in a 'phallo-logo-centric' line of filiation that descends from Aristotle's prime mover, the 'life that exceeds human life' $(14,146)$, to the monotheistic god that is eventually to be replaced with the people as sovereign. The people's dispersion of sovereignty in multiplicity appears to threaten the required unicity but may still hope to be recaptured if we limit the dispersion by birth, so that only the natural-born brothers are members of the nation state (61/92-3, cf. Derrida 1997, 105) or, in the case of the cosmopolitical, at least presuppose the roundness of the globe (18/39).

The patrilinear genealogy at the heart of sovereignty is complicated (as we will see, however, by no means overcome) by the notion of democratic fraternity. While the latter is dependent on allegedly natural birth, and so excludes not only those of different birth but also the sisters, brotherhood still represents a seemingly non-filial, nonintergenerational equality only because the father, the preceding and so unequal 'origin' of the brothers, has been killed (16-17/37-38). The patricide or regicide necessary for democratic equality as fraternity, we might say, again going quickly, is one of the reasons why the Western tradition thinks equality as exemplarily taking place among the living, and so as non-asymmetrical and non-intergenerational. This 
assumption, this presentism, makes of intergenerational justice not a pleonasm-there are reasons for thinking justice, as we will see in a moment, as intergenerational from the start-but a mere sub-discipline of applied ethics. The subordinate status of time and generations in justice is only rarely contested-for example, by Levinas's fecundity (Levinas 1969), itself not without patrilinear premises (cf. Derrida 1991; Derrida 1999, 67, 43, 139, 152), and by an ethics of care that insists on the ineluctable asymmetry between care-giver and cared-for (cf. Kittay 1999; Held 1995). Taking turns is also hardly ever associated with generational time; Aristotle, for one, seems to conclude from equality as the source of taking turns that the latter does not apply to naturally unequal relations, as those between men and women or younger and older people (I.12, 1259a37-1259b10). By contrast, the time of birth and death demands intergenerational turns in alternating asymmetries, as when the young turn into the elders and take their place in counselling and ruling.

If the father seeks to ensure the continuity, the circular return to itself, of his sovereign power by charging the son to continue his legacy (at times by claiming to pass on what he received himself from God as father, in the sense in which we say that the crown is not the king's property), how do the democratic brothers - those who beheaded, symbolically or physically, the father-king-maintain sovereignty? The brothers have to resurrect the circular continuity of sovereign power across death by agreeing to equitably share the paternal power as well as their newly won individual freedom. Given the impossibility of all ruling at once, in democracy, or any state that aims at free equals participating in power, this sharing, as Aristotle and Plato suggested, takes the form of taking turns, ruling and being ruled by turns (Derrida 2005a, 13, $24)$, in a circle that, while allowing alternation and so some reference to alterity, restricts its circulation among brothers and so permits the continuity of democratic sovereign power across generations. In this way, the 'double circulation' (24/46) of sovereignty around itself and of brothers taking turns mutually support each other in their exclusionary functions: the former by keeping out, at each turn, the non-brothers and the brothers by governing in turn to ensure the return of the sovereign to itself despite the threat that each new generation might represent. (We should recall here the fate of Thomas Jefferson's enlightened but unsuccessful proposal, just prior to the American constitutional convention in Philadelphia, city of brotherly love, to let each new birth cohort, after 19 years, ratify anew - or not - the democratic constitution.) 
We already know that this double circulation hides a monkey wrench throwing it off its mutually supporting, interlocking path. For another meaning of the 'free wheel' in Rogues is the 'free play' of différance that sovereign power is said to presuppose (25), both as a concept and as a practice, and that would not let it come back to itself. That is why 'ipsocentrism' is associated, right at the outset and rather abruptly at the end of $\$ 1$, with the suicidal autoimmunity (18) that we have already discussed as following from the originary non-coincidence of the (singular or collective) self but whose intergenerational aspects we have yet to explore. For what disrupts the continuity of the takingturns and makes the multi-focal wheel wobble is the birth and death that the fraternal brothers have feminized or privatized but without which they, too, cannot think sovereign continuity. To the extent birth, like the education of offspring, must be integrated into the polis, the brothers tended to politicize it as non-political, as the naissance that gives rise to the natural-born members, whether in the nation-state or not. That is why, in the confrontation with Nancy in Rogues as well as more generally in Politics of Friendship, Derrida is so critical of the link between fraternity and birth, birth and nationality (58/87; cf. Derrida 1997)..$^{9}$

There is, however, another thinking of birth in Derrida (cf. Boelderl 2007), one that he does not, despite the relevance, appear to link explicitly to the considerations of sovereignty. As we have seen, democracy (as well as justice) are thought from the 'undeconstructible' openness of the future, from the 'affirmative experience' of the absolute arrivant. Not only does Derrida view our life as an incompleteable coming to be born-'I am', he says, means 'I am (not yet) born', and wonders 'Who ever said that one was born just once?' (Derrida 1995b, 339/349). He also recognizes the birth of a child as one, though a privileged figure of the in-coming other, despite family preparations prior to any symbolic integration, including naming, after birth:

With the birth of a child - the first figure of the absolute arrivant-one can analyze the causalities, the genealogical, genetic, and symbolic premises, or the wedding preparations. But even if such an analysis could ever be completed, one could never reduce the element of chance [alea], the place of the taking-place; there will be someone who speaks, someone irreplaceable, an absolute initiative, another origin of the world... The openness of the future is worth more [than the ontological claim that there should be being rather than nothing]; that is the axiom of deconstruction, that on the basis of which it has always set itself in motion and which links it, as with the 


\section{Matthias Fritsch}

future itself, to otherness, to the priceless dignity of otherness, that is to say, to justice. It is also democracy as the democracy-to-come. (Derrida 2002a, 104-5)

The point of democracy to come remains 'to think and implement democracy ... while uprooting from it all these figures of friendship... which prescribe fraternity', including the family (Derrida 1997, 306). Democracy to come proceeds from another friendship beyond its determined, naturalized and familiarized forms, a friendship desertified as the 'anterior affirmation of being-together in allocution' (Derrida 1997, 249), as a non-chosen friendship or aimance that, as the 'law of originary sociability' (Derrida 1997, 231), entails a 'minimum of friendship or consent' (Derrida 1997, 214). In affirming sociality as enabling and threatening exposure to the other, the normativity or performativity that lies in saying 'yes' or 'come' to the event-to preceding contexts as well as to an open-ended future-affirms in the contingent origin of birth above all the futurity that makes no socius and no polis coincide with itself. The futurity that carries every fraternity beyond itself comes above all as the child: the arrivant that, in exceeding the polis and thus separating it from itself, discontinuously connects it with the next generation. The socius is a being-with-specters that, by not coinciding with itself, stretches into the past and the future (Derrida 1994, xviii). If social life is not contemporaneous with itself, justice in social relations must from the beginning be seen as intergenerational. Once more we encounter the idea that the common method of beginning with intragenerational justice, then seeking to 'extend' (Rawls) that atemporal justice for the living to the intergenerational realm as, for example, in Rawls (Rawls 1993, 20-21), relies on a faulty understanding of time.

If the child is 'another origin of the world' just as death is 'the end of the world, each time unique' (as the French title of Derrida's The Work of Mourning puts it: see Derrida 2001b), then nothing can guarantee the circularity of brothers taking turns. Rather, taking turns takes on another sense here: it refers to, gives to, an other who will also stand under the charge of legacy but whose birth cannot ever be controlled, by nature or by nationality. Even more, affirming the democratic turn-over turns into the affirmation of the mortality of life, the finitude of time, and vice versa.

To bear this out, let us briefly turn to the question that occupied Derrida so intently during the last years of his life, the question of learning to live together. His final interview Learning to live finally 
(Apprendre à viure afin) as well as the exordia to Rogues and Specters of Marx focus on this question, the question that is also the issue of intergenerational democracy. If democracy concerns the question of living together, what does this mean if life is living-on, always dying and being reborn? If, for example, the principle of popular sovereignty is silent on its own timing, so that 'majority rule in a given territory' immediately raises the question: majority at what time (see Thompson 2005)? If the disjointure of time renders sociality and thus justice possible, it also relates generations to one another across the abyss of birth and death.

In the exordium to Specters of Marx, Derrida argues that 'learning to live' means learning to come to terms with death, the death in life that disallows life, as well as a 'generation', to coincide with itself. Coming to terms with death, in turn, means relating to a non-provisional alterity (there called spectrality) that calls for justice, the 'welcome' to the other, even the demand for 'nonviolence' that the exigencies of sovereignty will prevent from being fully implemented (see Derrida 1996, 83; Derrida 1997, 231, 249). So if learning to live means coming to terms with death-and we should now add, with birth - then it means learning to live justly. Justice, in turn, is not restricted to one generation, but an intergenerational affair from the beginning. Derrida writes:

No ethics, no politics... seems possible and thinkable and just that does not recognize in its principle the respect for those others who are no longer or for those others who are not yet there, presently living, whether they are already dead or not yet born... justice must carry beyond present life, life as my life or our life. In general. For it will be the same thing for the 'my life' or 'our life' tomorrow, that is, for the life of others, as it was yesterday for other others: beyond therefore the living present in general. (Derrida 1994, xix f.; emphasis in original)

Tomorrow, then (though it is already happening), the present generation will be the dead for the next generation. And yesterday, the present generation was the future for the generation now dead. In saying this, we should be aware that the time of death and birth disrupt the collective singular 'generation' and its supposed unicity, as if iterability did not imply that each one already carried the singular other in him, anticipating her death as the end of the world, as Derrida suggested in his many responses to the deaths of others who now live on in mourning and memory alone (Derrida 2001b and Derrida 1989). Time is the time of sur-vival, of a living that never coincides with itself, and that therefore consists in taking turns. Life involves exchanging positions and stations 
in life, as the young become the old, and the unborn become the dead. It is this taking turns across the singular discontinuities of birth and death that disrupts the sovereign circle of brothers or compeers or free equals, who accept being ruled by another only because they know that their turn will come again. This other taking turns, by contrast, means letting go and passing on that over which one has (some) power. If democracy consists in the principled assent to power changing hands, then democracy to come insists that this is a switchover life demands anyway, even at every turn, making of the principled democratic credo also an affirmation of the unavoidable death that allows the demos to live on by the unpredictable birth of another. If justice implies a coming to terms with the alterity of death and birth as that of the other, then the democratic affirmation of taking turns renders it an intergenerational justice from the start. Democracy is a regime or an experience most well equipped to accept the fact that justice-learning to live-implies affirming life's turns, so that the dead and the unborn belong with us. The demos never coincides with itself; popular sovereignty is endlessly deferred to an open-ended future because life consists in dying and rebirth, a death and an open-endedness that democracy must confirm in principle.

This is what the elliptical 'email sending' of the exordium to Rogues expresses as the link between the gift of inheritance, the intergenerationality of life and democratic affirmation: 'The democracy to come: it is necessary that it give the time there is not' (Derrida 2005a, 1). Life depends on a gift of inheritance without which it cannot keep alive. But as the gift can also never be fully acknowledged or known or appropriated, it must be passed on to the future, in a turning that is the time of living on. Affirming this time of sur-vival is the condition of life, a life that consists in taking turns. Taking-turns is the enigma of the political that democracy in principle acknowledges, in fact affirms as the affirmation of friendship, an oath to fidelity or aimance that, as we heard, the Politics of Friendship calls the law of originary sociability (Derrida 1997, 231).

We should then read the child as an exemplary figure of the 'excessive gift' to the polis, the gift of which the exordium to Rogues says that with it we receive something 'unreceivable', a life beyond itself that 'remains the enigma of the political around which we endlessly turn' (Derrida 2005a, 4/22). The turning is enigmatic in that it does not come back to the same; instead, under the 'old and yet completely new and perhaps unthought name democracy', it turns 'toward the incalculability 
of another thought of life, of what is living in life [du vivant de la vie]' $(5 / 24)$. Democracy to come is the name of this incalculable life because, in affirming the future to come it is never sure of its spatial or temporal borders, perhaps not even of the boundaries of its life-form. Democracy's semantic indetermination implies interminable questions, not least as to why it may exclude children, and at what age minors should acquire the right to vote $(36 / 60,38 / 63)$. Of itself this political experience that is more than a form of government wonders whether its equality and citizenship must not be extended 'to all nonhuman living beings, or again, even beyond that, to all the nonliving, to their memory, spectral or otherwise, to their to-come' (53/81). If concern for the well-being and freedom of future people leads us to seek to include them, in however vicarious a form, among the citizens and the eventual turn-takers, the drift of this concern pushes even further: 'how far is democracy to be extended, the people of democracy, and the "each 'one"' of democracy? To the dead, to animals, to trees and rocks?' (54/82)

The bobbing wheel, we recall in closing, is to capture, at once, une fois, both the continuity and the discontinuity of generations coming on and off the stage of life. On this stage, the imperfect wheel depends at each turn on a quasi-revolutionary kick-start due to its lack of perfect roundness, a lack that may indeed also point to the origin of its stuttering turns in a life beyond human life, an elliptical cosmos. The gift of life is excessive not only because it also deals death, but because the living-on that results, in both its individual and collective generational turning, comes from and depends on the 'beyond of the living' (54/82). Generations also take turns inhabiting the ensemble of the living and the nonliving some (though hardly ever Derrida) call the earth, a turn-taking that affirms not only past and future lives, but that which these wobbling turn-takers willy-nilly share by turns. Sharing political sovereignty confirms life's dependency on a nonhuman element with which to take turns, one that no longer gives sovereignty a model of immutable circling around itself.

\section{References}

Aristotle (1960), Physics, trans. W. D. Ross, Oxford: Clarendon Press. Aristotle (2000), Politics, trans. Benjamin Jowett, New York: Dover.

Caputo, John D (1997), 'A Commentary' in Jacques Derrida, Deconstruction in a Nutshell, edited by John D. Caputo. New York: Fordham University Press, pp. 31-202. 


\section{Matthias Fritsch}

Derrida, Jacques (1978a), Edmund Husserl's Origin of Geometry: An Introduction, trans. J. P. Leavey, Stony Brook, NY: Nicolas Hays.

Derrida, Jacques (1978b), Writing and Difference, trans. Alan Bass, Chicago: University of Chicago Press. (L'écriture et la différence. Paris: Seuil, 1967.)

Derrida, Jacques (1979), 'Living On: Borderlines', in Deconstruction and Criticism, edited by Harold Bloom et.al, New York: Seabury, pp. 75-176.

Derrida, Jacques (1982), Margins of Philosophy, trans. Alan Bass, Chicago: University of Chicago Press. (Marges de la philosophie. Paris: Editions de Minuit, 1972)

Derrida, Jacques (1986a), Glas, trans. J.P. Leavey and R. Rand, Lincoln: University of Nebraska Press.

Derrida, Jacques (1986b), 'Declarations of Independence', New Political Science 15, pp. 7-15 ('Déclarations d'independance', Otobiographies: L'enseignement de Nietzsche et la politique du nom propre, Paris: Galilée, 1984)

Derrida, Jacques (1989), Mémoires: for Paul de Man, trans. C. Lindsay et. al, New York: Columbia University Press.

Derrida, Jacques (1990), 'Force of Law' Cardozo Law Review 11: 5-6, 919-1078.

Derrida, Jacques (1991), 'At this very Moment in this Work Here I am', Re-Reading Levinas, edited by Robert Bernasconi and Simon Critchley, Bloomington: Indiana University Press.

Derrida, Jacques, (1992a), The Other Heading: Reflections on Today's Europe, trans. Pascale Anne Brault and Michael Naas, Bloomington: Indiana University Press. (L'autre cap. Paris: Editions de Minuit, 1991)

Derrida, Jacques (1992b), Acts of Literature, edited by Derek Attridge, London: Routledge.

Derrida, Jacques (1992c), Given Time I : Counterfeit Money, trans. Peggy Kamuf, Chicago: University of Chicago Press. (Donner le temps. Paris: Editions Galilée, 1991)

Derrida, Jacques (1993), Aporias. Dying-awaiting (one another at the 'limits of truth'), trans. Thomas Dutoit, Stanford: Stanford University Press.

Derrida, Jacques (1994), Specters of Marx, trans. Peggy Kamuf, London: Routledge (Spectres de Marx. Paris: Editions Galilée, 1993)

Derrida, Jacques (1995a), The Gift of Death, trans. David Wells, Chicago: The University of Chicago Press.

Derrida, Jacques (1995a), Points... of Suspension. Interviews 1974-1994, ed. Elisabeth Weber, trans. Peggy Kamuf et al, Stanford: Stanford University Press (Points de suspension. Paris: Editions Galilée, 1992).

Derrida, Jacques (1996), 'Remarks on Deconstruction and Pragmatism,' Deconstruction and Pragmatism, edited by Chantal Mouffe, New York: Routledge.

Derrida, Jacques (1996b), Archive Fever. A Freudian Impression, trans. Eric Prenowitz, Chicago: University of Chicago Press.

Derrida, Jacques (1997), The Politics of Friendship, trans. George Collins, London: Verso. Politiques de l'amitié. Paris: Editions Galilée, 1994).

Derrida, Jacques (1998), 'Faith and Knowledge', Religion, edited by Jacques Derrida and Gianni Vattimo, Stanford: Stanford University Press.

Derrida, Jacques (1999), Adieu to Emmanuel Levinas, trans. Pascale Anne Brault and Michael Naas, Stanford: Stanford University Press. (Adieu. Paris: Editions Galilée, 1997).

Derrida, Jacques (2000), 'Foreigner Question' in Jacques Derrida and Anne Dufourmantelle, Of Hospitality, trans. Rachel Bowlby, Stanford: Stanford University Press. 
Derrida, Jacques (2001a), Arguing with Derrida, ed. Simon Glendenning, Oxford: Blackwell.

Derrida, Jacques (2001b), The Work of Mourning, ed. Pascale Anne Brault and Michael Naas, Chicago: University of Chicago Press (Chaque Fois Unique, La Fin Du Monde, Paris: Editions Galilée, 2003)

Derrida, Jacques (2002a), Negotiations: Interventions and Interviews, 1971-2001, Stanford: Stanford University Press.

Derrida, Jacques (2002b), Echographies of Television: Filmed Interviews, with Bernard Stiegler, trans. Jennifer Bajorek, Cambridge: Polity.

Derrida, Jacques (2002c), Without Alibi, ed., trans. Peggy Kamuf, Stanford: Stanford University Press.

Derrida, Jacques (2004), For What Tomorrow... A Dialogue, with Elisabeth Roudinesco, trans. Jeff Fort, Stanford: Stanford University Press.

Derrida, Jacques (2005a), Rogues. Two Essays on Reason, trans. Pascale-Anne Brault and Michael Naas, Stanford: Stanford University Press. (Voyous. Paris: Editions Galilée, 2003.)

Derrida, Jacques (2005b), Sovereignties in Question. The Poetics of Paul Celan, New York: Fordham University Press.

Derrida, Jacques (2008), Psyche: Inventions of the Other, Volume II, ed. Peggy Kamuf and Elizabeth Rottenberg, Stanford: Stanford University Press.

Derrida, Jacques (2009), The Beast and the Sovereign, Vol.1. trans. Geoffrey Bennington, Chicago: University of Chicago Press.

Dryzek, John (1996), Democracy in Capitalist Times, Oxford: Oxford University Press.

Foucault, Michel (2002), Society must be defended: Lectures at the Collège de France, 1975-76, New York: Picador.

Fritsch, Matthias (2002), "Derrida's Democracy to Come", Constellations: An International Journal of Critical and Democratic Theory 9:4, 574-597.

Fritsch, Matthias (2005), The Promise of Memory. History and Politics in Marx, Benjamin, and Derrida, Albany: SUNY Press.

Fritsch, Matthias (2008), 'Antagonism and Democratic Citizenship (Schmitt, Mouffe, Derrida)' Research in Phenomenology 38:2, pp. 174-197.

Fritsch, Matthias (2011/2012), "Deconstructive Aporias: Both Quasi-Transcendental and Normative" Continental Philosophy Review (forthcoming)

Gardiner, Stephen (2006), 'A Perfect Moral Storm. Climate Change, Intergenerational Ethics, and the Problem of Corruption', Environmental Values 15:3, pp. 397-413.

Garvey, James (2008), The Ethics of Climate Change, London: Continuum.

Giddens, Anthony (2009), The Politics of Climate Change, Cambridge: Polity Press.

Gosseries, Axel (2009), 'Three Models of Intergenerational Reciprocity' in Gosseries, Axel, Lukas H. Meyer (eds.) Intergenerational Justice, Oxford: Oxford University Press.

Habermas, Jürgen (1990), Moral Consciousness and Communicative Action, trans. C. Lenhardt, S. Nicholsen Weber, Cambridge: MIT Press.

Habermas, Jürgen (1986), Autonomy and Solidarity. Interviews with Jürgen Habermas, ed. P. Dews, London: Verso.

Hägglund, Martin (2008), Radical Atheism: Derrida and the Time of Life, Stanford: Stanford University Press.

Harvey, David (1990), The Condition of Postmodernity, Oxford: Blackwell.

Held, Virginia (ed.) (1995), Justice And Care: Essential Readings In Feminist Ethics, Boulder: Westview Press. 


\section{Matthias Fritsch}

Kittay, Eva (1998), Love's Labor: Essays on Women, Equality, and Dependency, New York: Routledge.

Levinas, Emmanuel (1969), Totality and Infinity, trans. Alphonso Lingis, Pittsburgh: Duquesne University Press, (Totalité et infini. Essai sur l'extériorité. La Haye: M. Nijhoff, 1961)

Mason, George (1970), The Papers of George Mason, ed. Robert A. Rutland, Chapel Hill, NC: University of North Carolina Press.

Naas, Michael (2007), 'Comme si, comme ça: Phantasms of Self, State, and a Sovereign God' Mosaic 40:2, pp. 1-26.

Naas, Michael (2008), Derrida From Now On, New York: Fordham University Press.

Rabinow, Paul, and Nikolas Rose (2006), 'Biopower Today' BioSocieties 1, pp. 195-217.

Rawls, John (1993), Political Liberalism, New York: Columbia University Press.

Rottenberg, Elizabeth (2006), 'The legacy of autoimmunity', Mosaic 39:3, pp. 1-14.

Shearman, David, and Joseph Wayne Smith (2007), The Climate Change Challenge and the Failure of Democracy, London: Praeger.

Thompson, Dennis. F. (2005), 'Democracy in Time: Popular Sovereignty and Temporal Representation', Constellations 12:2, pp. 245-261.

Thompson, Dennis. F (2010), 'Representing future generations: political presentism and democratic trusteeship', Critical Review of International Social and Political Philosophy, 13:1, pp. 17-37.

Tremmel, Jörg Chet (2006), 'Establishing intergenerational justice in national constitutions' in Tremmel Jörg Chet (ed.). 2006. Handbook of Intergenerational Justice. Cheltenham: Edward Elgar, pp. 187-213.

Wood, Paul. M. (2008), 'Sustainability Impeded: Ultra Vires Environmental Issues' Environmental Ethics 30:2, pp. 159-174.

\section{Notes}

* The author thanks the Alexander-von-Humboldt Foundation for institutional support, Christoph Horn for pointing to relevant passages in Aristotle, and two anonymous reviewers for their helpful comments. Needless to say, remaining inadequacies remain my responsibility.

1. Page numbers without author and date refer to Derrida's Rogues (2005a). If there is a second page number, it refers to the French original as listed in the bibliography. The original is usually indicated only if I added French terms in square brackets or altered the translation.

2. Michael Naas kindly explained to me that, being aware of the problem, he and his co-translator found that in English one can hear the geometric figure in the rhetorical 'ellipsis'. If so the former is merely deemphasized, not dropped.

3. Online Etymology Dictionary at: www.etymonline.com (last access 10 January 2011)

4. The parenthetical qualification - that democracy is for Derrida not just a form of government, and conversely, where it is a regime it becomes a 'quasi-regime' due to its unboundedness, plasticity, and openness to its own transformation (Derrida 2005a, 25/48; cf. Fritsch 2002; 2008) - is important as Aristotle did not restrict the usefulness of rotation to democracy. The Politics in fact finds it indispensable to the polity, the best regime, for equality demands sharing power by turns (III.4, 1277b7-17). Most other passages that discuss kata meros similarly ground it in equality and the sharing of freedom or power (III.6, 1278b37-1279a13; II.2, 1261a32-1261b10; VI.2, 1317b1-25; see also the next note). Democracy's 
deficit lies for Aristotle in this regard not in sharing freedom equitably but in how democracy interprets this freedom, namely, as the freedom to do what one wants (VI.1, 1317b11). In response to this, Derrida argues that it has always been difficult to distinguish good freedom (eleutheria) from bad freedom or license (exousia; Derrida 2005a, 21-27/43-49).

5. In his discussion of the prime mover as figuring sovereignty, Derrida flags that Aristotle determines it as a divine 'life' that exceeds the life of human beings (Derrida 2005a, 15/36). In the now partly published lecture courses that belong to the same research project as Rogues, Derrida explores in greater detail the relation between the beast and the sovereign, both typically determined as inside as well as outside the political, the latter in fact as itself a kind of life that rules over the living from inside the legal and political order it makes possible and an exception to it (see Derrida 2009). This position both inside and outside again recalls what Writing and Difference says about the centre being both inside and outside a structure (Derrida 1978, 278ff.). To explore this relation between the principle of rotation (cosmological and political) and the canonical position of humans between God's perfect roundness and animal desire, we should interpret an Aristotelian passage in Politics III.16 that Derrida does not cite. There, Aristotle derives taking turns in occupying offices not just out of the demand to share power equitably, as in most other passages, but out of the corruptibility of human animals whose execution of the law always falls short of 'law as reason unaffected by desire' (1287a16-32, trans. Benjamin Jowett). To call for the rule of law is to call for god or reason to rule, but as law must be executed and applied equitably, it also requires human executioners, whose beastly appetites will lead to abuse unless their time in office is limited and alternates among them. In yet another passage, Aristotle argues against Plato that the necessity of rotation in different offices should lead us not to demand too much unity of the city (Pol. II.2, 1261b). These passages deserve closer treatment than I have space for here.

6. Habermas for example argues that the higher order norms of argumentative discourses include, on the logical-semantic level, the idealizing and counterfactual presupposition that speakers use expressions with the same meaning, that a predicate has to be applied to different but sufficiently similar objects, and the like (Habermas 1990, 87). Occasionally, Habermas admits (even with reference to Derrida) that the dependence of meaning on in toto unthematizable and shifting contexts implies the interminability of seeking understanding in transparent certainty, as well as the impossibility of the absolute identity of meaning to itself (Habermas 1986, 197f.).

7. A similar passage in Rogues, one that insists on the interminability of democracy due to its constitutive relation to différance as to the deferral to the future to come, goes so far as to claim that the reference to the alterity of the other cannot but be denied by the self that wishes to come back to itself: 'For what is also and at the same time at stake - and marked by this same word in différance-is différance as reference or referral [renvoi] to the other, that is, as the undeniable, and I underscore undeniable, experience of the alterity of the other, of heterogeneity, of the singular, the not-same, the different, the dissymmetric, the heteronomous. I underscore undeniable to suggest only deniable, the only protective recourse being that of a send-off [renvoi] through denial' (28). Hence, the reference to the phantom, the spectral, and the simulacrum in the passage from Specters cited in the body of the text. For an analysis of this necessary illusion of oneself, see Naas 2007; Fritsch 2008.

8. The same issue emerged in Iraq after the US invasion: Should Islamic fundamentalists be allowed to vote and stand for elected office if their express aim is to end democratic rule? Must a democracy not, as the Algerian state did in 


\section{Matthias Fritsch}

1992, halt, by sovereign decision, democratic elections that threaten to overthrow democracy, thus deferring democracy to a better time? Should this not have been done in 1933 in Germany, for example? A further example Derrida gives, this time as a 'more visibly auto-immune process', concerns the reaction of the US and other Western democracies to the 2001 terrorist attacks: the restrictions of democratic freedoms in order, allegedly, to protect itself against the enemies of democracy (Derrida 2005a, 39ff.). If democracy is the only quasi-regime that is open to its own historical transformation (Derrida 2005a, 25), this openness can extend itself to the point of risking democracy's own abdication. As Derrida puts it: 'the alternative to democracy can always be represented as a democratic alternation' (Derrida 2005a, 31).

9. There are, of course, other reasons, many of them taught us by Foucault, to critically analyze 'biopower' and the increasing attempt to control the birth rate of populations along with health policies and mortality rates, at the service of maximizing the economic and military might of increasingly competitive states in the Westphalian order and beyond. See in particular Foucault 2002; for an analysis of recent developments in this area, see Rabinow and Rose 2006. 